ISSN (Print) : 1412-7601

ISSN (Online) : 2654-8712

Volume 7, No.1 Maret 2021

EKONOBIS

\title{
Analisis Pengembangan Agrowisata Berbasis Partisipasi Masyarakat Lokal Di Kecamatan Gangga Kabupaten Lombok Utara
}

Emi Salmah, Titi Yuniarti, Tuti Handayani.

Universitas Mataram

ARTICLE INFO
Keywords:
Agrotourism, community
participation, qualitative
research

Kata Kunci:

Agrowisata, Partisipasi

masyarakat, penelitian

kualitatif

\begin{abstract}
This study aims to, 1). Assessing the involvement of local communities in the development of agro-tourism in Gangga District, North Lombok Regency, 2). Formulate an agro-tourism development model that prioritizes local community participation. This research is expected to be useful as 1). Material for consideration by the Government to involve local communities in tourism activities. 2. As a reference material for future researchers on the same problem. This type of research is descriptive, which uses primary data secondary data, data collection methods, observation, in-depth interviews (indep interview) and literature review. Samples will be taken from each village of 25 people, so the total number of respondents is 50 people. The analysis technique used is qualitative analysis technique. The results of the research show that the community does not participate in planning and monitoring too much. The community participates in the implementation by providing home stays / bungalows that are often rented by foreign tourists. There are local people who have started businesses in the Agro sector close to tourist destinations by planting organic melons (in groups), with the hope that tourists who enjoy the natural scenery / waterfalls are also invited to enjoy melons by picking and enjoying them directly on the spot by means typical of the village. They want Gangga District to have a special brand in agro-tourism, namely growing melons whose color is Orange.

ABSTRAK: Penelitian ini bertujuan untuk, 1). Mengkaji keterlibatan masyarakat lokal dalam pengembangan agrowisata di Kecamatan Gangga Kabupaten Lombok Utara, 2). Merumuskan model pengembangan agrowisata yang mengedepankan partisipasi masyarakat lokal. Penelitian ini diharapkan bermanfaat sebagai 1). Bahan pertimbangan Pemerintah untuk mengikutsertakan masyarakat lokal dalam kegiatan pariwisata.2. Sebagai bahan referensi bagi peneliti peneliti selanjutnya pada masalah yang sama. Jenis penelitian yang digunakan adalah Diskriptif, yang menggunakan data primer data Sekunder, metode pengumpulan data, observasi, Wawancara secara mendalam (indepth interview) dan telaah pustaka. Sampel akan diambil masing masing desa 25 orang, sehingga total responden 50 orang. Penelitian ini menggunakan Tehnik analisa kualitatif. Hasil penenitian menunjukkan bahwa masyarakat tidak terlalu besar partisipasinya dalam perencanaan dan pengawasan. Masyarakat berpatsipasi dalam implementasi dengan menyediakan home Stay/bungalow yang sering disewa oleh para turis asing. Masyarakat local sudah ada yang memulai usaha dibidang Agro dekat dengan Destinasi wisata dengan menanam Melon organik (berkelopmpok), dengan harapan, wisatawan yang menikmati pemandangan alam / air terjun, diajak juga untuk menikmati buah melon dengan cara memetik dan menikmati langsung di tempat dengan cara/khas desa. Mereka ingin Kecamatan Gangga mempunyai brand khusus dalam agrowisata yakni menanam melon yang warnamya Orange.
\end{abstract}

Corresponding Author:

Alamat : Program Studi Ekonomi Pembangunan, Fakultas Ekonomi dan Bisnis, Universitas Mataram, Jln. Majapahit No. 62 Mataram.

e-mail: emisalmah@unram.ac.id 


\section{PENDAHULUAN}

\section{Latar Belakang}

Pariwisata sebagai suatu aktivitas, adalah suatu fenomena sosial yang sangat kompleks dan menyatu dalam segala aspek kehidupan manusia. Pariwisata merupakan keseluruhan kegiatan untuk penataan dan pelayanan terhadap pemenuhan kebutuhan berwisata, sehingga memilik dampak yang besar sekali terhadap sistem nilai masyarakat, baik dampak yang bersifat positif maupun dampak yang bersifat negatif.

Provinsi Nusa Tenggara Barat (NTB) merupakan salah satu daerah Destinasi wisata di Indonesia yang telah dikunjungi oleh banyak wisatawan baik dalam negeri maupun luar negeri. Salah satu daya tarik bagi wisatawan untuk berkunjung ke suatu daerah adalah keindahan alamnya ( pantai, pegunungan, cagar budaya dan lain lainnya). Provinsi NTB yang terdiri dari dua (2) Pulau yakni P. Lombok dan P. Sumbawa, mempunyai banyak obyek wisata yang menarik untuk dikunjung yang tersebar pada 10 ( sepuluh ) kabupaten / Kota yang ada di NTB. Salah satunya adalah di Kecamatan Gangga Kabupaten Lombok Utara (KLU).

Obyek wisata di KLU beranekaragam, seperti pantai, Gili, air terjun, wisata budaya dan wisata alam lainnya yang sudah cukup terkenal di Nusantara dan Manca Negara. Obyek obyek wisata ini tersebar diseluruh wilayah KLU. Dari beberapa obyek wisata yang ada di KLU, ada beberapa yang ada di Kecamatan Gangga, yaitu air terjun. Kondisi ini berhubungan dengan letak Kecamatan Gangga yang di perbukitan dan dataran tinggi.

Jika dilihat dari keadaan dan letak geografis Kecamatan Gangga, dapat dikembangkan sebagai objek wisata agro. Potensi objek wisata tersebut merupakan daerah wisata agro yang berupa pegunungan, perbukitan dimana mata pencaharian penduduknya berasal dari hasil pertanian dan perkebunan. Dari hasil agro yaitu pertanian dan perkebunan seperti kopi, coklat, jambu mette dan aneka buah antara lain; durian, manggis, jambu batu dan lain lainnya. Terdapat juga berbagai macam jenis sayur-sayuran yang dapat dilestarikan dan dikembangkan sebagai salah satu daya tarik utama pariwisata agro sehingga Kecamatan Gangga memiliki potensi agro yang cukup baik untuk dikembangkan sebagai pariwisata agro, yang dapat meningkatkan perekonomian penduduk setempat. Oleh kareha itu keterlibatan / partisipasi 
masyarakat sangat diperlukan dalam pengembangan pariwisata.

Munculnya proses partisipasi masyarakat lokal dalam kegiatan agrowisata mendasarkan atas dua perefektif, Pertama; pelibatan masyarakat setempat dalam pemilihan, perancangan, perencanaan dan pelaksanaan, program yang akan mewarnai kehidupan masyarakat. Kedua; partisipasi transformasional sebagai tujuan untuk mengubah kondisi lemah dan marjinal menjadi berdaya dan mandiri.

Partisipasi masyarakat merupakan prasyarat penting dalam pelaksanaan pembangunan. Pembangunan yang tidak melibatkan masyarakat akan cenderung memarginalkan masyarakat itu sendiri. Namun pada kenyataannya sering terjadi pengabaian partisipasi masyarakat, sehingga masyarakat masih menjadi objek dari pelaksanaan pembangunan.

Berdasarkan permasalahan tersebut perlu dilakukan suatu penelitian tentang Pengembangan Agrowisata Berbasis Partisispasi Masyarakat Lokal di Kecamatan Gangga Kabupaten Lombok Utara. Sehingga masyarakat dapat merasakan manfaat dengan andanya kegiatan agrowisata tersebut.

\section{Rumusan Masalah}

Dari latar belakang di atas dapat dirumuskan permasalahan sebagai berikut:

1. Bagaimana keterlibatan masyarakat dalam pengembangan agrowisata di Kecamatan Gangga Kabupaten Lombok Utara

2. Bagaimana model pengembangan agrowisata yang mengedepankan partisipasi masyarakat lokal di Kecamatan Gangga.

\section{Tujuan dan Manfaat Penelitian}

\section{Tujuan Penelitian}

1. Mengkaji keterlibatan masyarakat lokal dalam pengembangan agrowisata di Kecamatan Gangga Kabupaten Lombok Utara

2. Merumuskan model pengembangan agrowisata yang mengedepankan partisipasi masyarakat lokal

\section{Manfaat Penelitian}

1. Sebagai bahan pertimbangan Pemerintah untuk mengikutsertakan masyarakat lokal dalam kegiatan pariwisata.

2. Sebagai bahan referensi bagi peneliti peneliti selanjutnya yang berminat pada masalah yang sama, 


\section{KAJIAN PUSTAKA}

\section{Pengertian Umum Pariwisata}

Istilah pariwisata berasal dari dua suku kata, yakni pari dan wisata. Pari berarti banyak, berkali-kali atau berputar-putar. Wisata berarti perjalanan atau bepergian. Jadi pariwisata adalah perjalanan atau bepergian yang dalam hal ini sinonim dengan kata "travel" dalam bahasa Inggris. Atas dasar itu, maka kata "pariwisata" dapat diartikan sebagai perjalanan yang dilakukan berkali-kali atau berputar-putar dari suatu tempat ke tempat yang lain.

Menurut Drs. Oka A. Yoeti (1982) Wisata adalah suatu perjalanan yang dilakukan sementara waktu, yang diselenggarakan dari satu tempat ke tempat lain dengan maksud bukan untuk berusaha (bisnis) atau mencari nafkah di tempat yang dikunjungi, tetapi semata- mata untuk menikmati perjalanan tersebut guna pertamasyaan dan rekreasi atau untuk memenuhi keinginan yang beraneka ragam, sedangkan pariwisata juga berarti perpindahan orang untuk sementara dan dalam jangka waktu pendek ke tujuantujuan di luar tempat dimana mereka biasanya hidup dan bekerja, dan kegiatankegiatan mereka selama tinggal di tempattempat tujuan tersebut (Soekadijo, 2000:3)
Di Indonesia, pengertian wisatawan tercantum dalam Instruksi Presiden RI No. 9 tahun 1969, yaitu setiap orang yang berpergian dari tempat tinggalnya untuk berkunjung ke tempat lain dengan menikmati perjalanan dan kunjungan itu. Pengembangan menurut Yulius (1986:27) menjelaskan bahwa berdasarkan asal katanya pengembangan berasal dari kata kembang yang berarti berkembang dan tumbuh menjadi besar serta bertambah baik dan semakin sempurna. Perkembangan ini dalam bentuk wujud mutu dalam artian kualitas dan kuantitas.

Dinata J (1986:2) pengembangan adalah usaha untuk memajukan, memperbaiki dan meningkatkan sesuatu yang telah ada menjadi lebih baik dari sebelumnya dalam mendukung pembangunan sosial dan ekonomi.

Jadi suatu pengembangan pariwisata pada hakekatnya adalah suatu usaha yang dilakukan secara terus menerus, dengan maksud bahwa pengembangan tersebut harus mampu memberikan daya saing terhadap daerah tujuan wisata (DTW) yang lainnya baik dari segi pelayanan atraksi wisata maupun obyek wisata yang ada sehingga dapat menyesuaikan diri dengan selera wisatawan.

Wisata berasal dari kata sansekerta yang berarti perjalanan, maksudnya kegiatan 
yang dilakukan untuk memenuhi kebutuhan fisik atau untuk bersosialisasi dan interaksi yang lebih mendalam agar dapat lebih membutuhkan pemahaman dan penghargaan terhadap daerah yang dikunjungi.

Menurut Samsurijal (1997:31) menjelaskan bahwa suatu tindakan untuk mencari suasana baru yang sama sekali berlainan dengan kehidupan sehari-hari, karena dengan meninggalkan kebiasaan sehari-hari dan mengalami hal yang belum pernah dialami, mereka berharap dapat membutuhkan rasa sukaria dan suasan bahagia.

\section{Jenis Pariwisata}

Sesuai dengan potensi yang dimiliki atau kawasan yang ditinggalkan nenek moyang pada suatu negara, maka timbullah bermacam-macam jenis pariwisata yang dikembangkan sebagai kegiatan yang lama kelamaan mempunyai ciri tersendiri berdasarkan letak geografis, alasan/tujuan perjalanan, saat atau berkunjung dan pembagian menurut obyeknya. Sedangkan jenis pariwisata dapat dikelompokkan dalam: wisata budaya, kesehatan, olahraga, komersial, industri, politik, konvesi, sosial, pertanian, maritim/bahari, cagar alam, dan pilgrim.
Berdasarkan penentuan obyek/tujuan obyek wisata jenis dan tempat obyek wisata dibedakan atas :

1. Wisata Alam

2. Wisata Budaya

3. Wisata Remaja

4. Wisata pendidikan

5. Wisata Petualangan

6. Wisata Leasure

7. Wisata Sosial Budaya

8. Agrowisata.

\section{Pengertian Agrowisata}

Agrowisata merupakan bagian dari obyek wisata yang memanfaatkan usaha pertanian (agro) sebagai objek wisata. Tujuannya adalah untuk memperluas pengetahuan, pengalaman rekreasi, dan hubungan usaha dibidang pertanian. Melalui pengembangan agrowisata yang menonjolkan budaya local dalam memanfaatkan lahan, kita bisa meningkatkan pendapatan petani sambil melestarikan sumber daya lahan, serta memelihara budaya maupun teknologi lokal (indigenous knowledge) yang umumnya telah sesuai dengan kondisi ingkungan alaminya.

Agrowisata dapat dikelompokkan ke dalam wisata ekologi (eco-tourism), yaitu kegiatan perjalanan wisata dengan tidak merusak atau mencemari alam dengan tujuan untuk mengagumi dan menikmati 
keindahan alam, hewan, atau tumbuhan liar di lingkungan alamnya serta sebagai sarana pendidikan.

\section{Macam-macam Agrowisata}

1. Agrowisata Ruang Terbuka Alami Obyek agrowisata ruangan terbuka alami berada pada areal dimana kegiatan tersebut dilakukan langsung oleh masyarakat petani setempat sesuai dengan kehidupan keseharian mereka.

2. Agrowisata Ruang Terbuka Buatan Kawasan agrowisata yang terbuka buatan ini dapat didesain pada kawasan-kawasan yang spesifik, namun belum dikuasai atau disentuh oleh masyarakat adat.

Untuk membantu meningkatkan masyarakat petani yang berada di pedesaan, prioritas pengembangan agrowisata hendaknya lebih diarahkan pada pengembangan agrowisata ruang terbuka (Subowo, dikutip dari Warta Penelitian dan Pengembangan Pertanian Vol.24 No.1, 2002).

\section{Ciri Wisata Agro}

Ciri-ciri wisata agro yaitu :

1. Sebagian besar masyarakat di desa tersebut bergerak di bidang pertanian atau Agribisnis yang utuh.
2. Sistem usaha tani pertanian yang mencakup usaha tanaman pangan, holtikultura , pertanian, peternakan, perkebunan dan kehutanan.

3. Sistem jasa-jasa penunjang (kegiatan yang menye'diakan jasa bagi agribisnis) seperti: perkreditan, asuransi, transportasi, penelitian dan pengembangan, pendidikan, penyuluhan, infrastruktur, dan kebijakan pemerintah.

4. Kehidupan masyarakat di Desa Agro sama dengan suasana kehidupan di perkotaan, karena infrastruktur yang ada di Desa Agro diusahakan tidak jauh berbeda dengan di Kota.

5. Desa Wisata Agro yang bergerak di bidang pertanian yang dapat dibudidayakan dan mempunyai keunikan lokal tersendiri untuk dapat di kembangkan sebagai Desa Wisata Agro.

6. Kegiatan sebagian besar masyarakat di Desa tersebut didominasi oleh kegiatan pertanian atau agribisnis, termasuk didalamnya usaha industri (pengolahan) pertanian, perdagangan hasil-hasil pertanian 
(termasuk perdagangan untuk kegiatan ekspor), perdagangan agribisnis hulu (sarana pertanian dan permodalan), Agrowisata dan jasa pelayanan.

7. Adanya keterkaitan antara Kota dengan Desa (urban-rural linkages) yang saling membutuhkan, dimana kawasan pertanian di perdesaan mengembangkan usaha budi daya (on farm) dan produk olahan Skala rumah tangga (off farm), sebaliknya kota menyediakan fasilitas untuk berkembangnya usaha budi daya dan agribisnis seperti penyediaan sarana pertanian antara lain:modal, teknologi, informasi, peralatan pertanian dan lain sebagainya.

\section{Manfaat Pengembangan Agrowisata}

Pengembangan agrowisata sesuai dengan kapabilitas, tipologi,, dan fungsi ekologis lahan akan berpengaruh langsung terhadap kelestarian sumber daya lahan dan pendapatan petani serta masyarakat sekitarnya. Kegiatan ini secara tidak langsung akan meningkatkan persepsi positif petani serta masyarakat sekitarnya akan arti pentingnya pelestarian sumber daya lahan pertanian. Pengembangan agrowisata pada gilirannya akan menciptakan lapangan pekerjaan, karena usaha ini dapat menyerap tenaga kerja dari masyarakat desa, sehingga dapat menahan atau mengurangi arus urbanisasi yang semakin meningkat saat ini. Manfaat yang dapat diperoleh dari agrowisata adalah melestarikan sumber daya alam, dan meningkatkan pendapatan petani/masyarakat sekitar lokasi wisata.

\section{Partisipasi Masyarakat}

Istilan Partisipasi sering digunakan dalam kajian tentang anggota masyarakat baik formal maupun non formal. Partisipasi merupakan keikutsertaan masyarakat dalam suatu kegiatan. Jadi partisipasi adalah keterlibatan sejumlah besar orang dalam usaha meningkatkan kesejahteraan sosial ( Joyo Martono dalam , 1991, 63 ). Partisipasi pengelolaan sumberdaya alam nasional, termasuk dalam pengembangan pariwisata sangat penting dimasyarakatkan kepada semua pelaku yang terlibat. Partisipasi tidak hanya berasal dari masyarakat, tetapi partisipasi harus datang dari semua pihak, baik rakyat/ masyarakat maupun pemerintah, pihak swasta dan lainnya.

\section{Perlunya Partisipasi Masyarakat}

Pada umumnya sejumlah kalangan sepakat perlu dikembangkan partisipasi sebagai upaya menyertakan masyarakat seluasluasnya yang mendorong, berkembangnya proses kebersamaan. Munculnya proses 
partisipasi dalam rangka pemberdayaan masyarakat mendasarkan atas dua pendekatan. Pertama; pelibatan masyarakat dalam pemilihan, perancangan, perencanaan dan pelaksanaan program, sehingga dengan demikian adanya jaminan pola sikap dan pola pikir serta nilai-nilai dan pengetahuannya ikut dipertimbangkan. Kedua; membuat umpan balik yang pada hakikatnya merupakan bagian yang tidak terlepaskan dari kegiatan pembangunan..

\section{METODE PENELITIAN}

\section{Lokasi Penelitian}

Penelitian ini dilakukan di Kecamatan Gangga Kabupaten Lombok Utara. Lokasi penelitian ditentukan dengan pertimbangan bahwa kawasan tersebut memiliki potensi dan daya tarik wisata yang apabila dikembangkan dapat menjadi destinasi wisata di Kabupaten Lombok Utara khususnya dan NTB umumnya.

\section{Jenis Penelitian dan Sumber Data}

Jenis penelitian yang digunakan adalah deskriptif kualitatif. Dalam penelitian ini menggunakan data primer dan data sekunder.

Data yang ada kaitannya dengan penelitian ini adalah berupa data primer dan sekunder yang diperoleh dari instansiinstansi terkait.

\section{Populasi dan Sampel}

populasi dalam penelitian ini adalah seluruh masyarakat di Kecamatan Gangga Khususnya masyarakat yang terlibat dalam kegiatan pariwisata, antara lain: Kelompok Sadar Wisata ( Pokdarwis ), pelaku pariwisata, tokoh Masyarakat, Tokoh adat/agama dan para pengambil kebijakan / stacholder yang terkait dengan pariwisata ( Dinas Pariwisata Kabupaten Lombok Utara ).

Dari 5 Desa yang ada di Kecamatan Gangga akan diambil 2 desa sampel yang memiliki lokasi wisata terutama terkait dengan agrowisata, yakni Desa Genggelang dan Desa Rempek. Sampel akan diambil masing masing 25 orang pada 2 desa sampel, yakni 5 orang Pokdarwis, 5 orang pelaku wisata , 5 orang tokoh masyarakat, 5 orang tokoh agama/adat dan 5 orang stacholder / pengambil kebijakan, sehingga keseluruhan responden berjumlah 50 orang. Diharapkan dari sampel ini akan diperoleh data yang menggambarkan keterlibatan masyarakat dalam pengembangan agrowisata di Kecamatan Gangga Kabupatem Lombok Utara.

\section{Metode Pengumpulan Data}

Metode pengumpulan data dalam penelitian ini adalah : 1 . Metode Wawancara, 2. Metode Observasi, 3. Telaah Pustaka 


\section{Metode Analisis Data}

Tehnik analisa yang digunakan dalam penelitian ini adalah tehnik kualitatif, dimana peneliti menggunakan kata kata secara diskriptif untuk menjelaskan fakta yang diperoleh. Alwasilah ( dalam Ade Jafar Sidiq dkk) menjelaskan bahwa uji keabsahan data dilakukan supaya diperoleh kebenaran dan kejujuran dari sebuah diskripsi, kesimpulan, penjelasan, tafsiran dan segalan jenis laporan. Pada penelitian ini uji validitasi meliputi: Validitasi Diskripsi, b).Validasi Interpretasi, c. Validasi teori .

Teknik analisa data dilakukan dengan tiga cara alur kegiatan yang terjadi secara bersamaan, yaitu reduksi data, penyajian data dan penarikan kesimpulan atau verivikasi, ( Miles 1992, dalam Ade Jafar Sidiq dkk) .

\section{HASIL DAN PEMBAHASAN}

\section{Kondisi Demografis}

Pertumbuhan penduduk akan selalu dikaitkan dengan tingkat

\section{Gambaran Umum Lokasi Penelitian.}

\section{Kondisi Geografis dan Penduduk}

Kecamatan Gangga merupakan salah satu dari lima (5) Kecamatan yang ada di Kabupaten Lombok Utara. Kecamatan Gangga terdiri dari 5 desa dan 77 dusun, dengan ketianggiam di kemiskinan,kematian dan perpindahan penduduk atau migrasi baik perpindahan ke luar maupun dari luar. Pertumbuhan penduduk adalah peningkatan atau penurunan jumlah penduduk suatu daerah dari waktu ke waktu. Pertumbuhan penduduk yang minus berarti jumlah penduduk yang ada pada suatu daerah mengalami penurunannyang bias disebabkan oleh berbagai kondisi. Pertumbuhan penduduk meningkat jika jumlah kelahiran dan perpindahan penduduk dari luar ke dalam lebih besar dari jumlah kematian dan perpindahan penduduk dari dalam ke luar. Jumlah penduduk di Kabupaten Lombok Barat dari tahun ketahun terus meningkat. Berdasarkan data dari Badan Pusat Statistik Kabupaten Lombok Barat sampai dengan tahun 2014 data jumlah penduduk diKabupaten Lombok Barat telah mencapai 644.586 jiwa yang terdiri dari laki-laki sekitar 315.094 Jiwa dan perempuan 329.492 jiwa.

atas permukaan laut ( DPL ) 5- 1000 meter. Kecamatan ini berbatasan langsung dengan Laut Jawa di sebelah Utara, Kecamatan Khayangan di sebelah Timur, Kabupaten Lombok Tengah di sebelah Selatan serta Kecamatan Tanjung sebelah Barat ( 
Kecamatan Gangga Dalam Angka, 2017).

Kecamatan Gangga memiliki lima desa dengan Desa Gondang sebagai ibu kota Kecamatan. Luas wilayah Kecamatan Gangga adalah 157,35 $\mathrm{km}^{2}$ atau sekitar 19,44 persen dari luas wilayah Kabupaten Lombok Utara. Desa yang terluas wilayahnya adalah Desa Bentek yaitu 37,27 $\mathrm{km}^{2}$, sedangkan desa yang tersempit luas wilayahnya adalah Desa Gondang yaitu $29,20 \mathrm{Km}^{2}$. Kecamatan Ganggat terdiri dari lima desa, tiap tiap desa memiliki karakter masing masing, ada desa pantai, desa perbukitan dan desa pertanian/perkebunan.

Tabel 1 Jumlah Penduduk, Luas Wilayah dan Kepadatan Penduduk Di Kecamatan Gangga Tahun 2017

\begin{tabular}{|c|c|c|c|c|c|c|}
\hline \multirow[t]{2}{*}{ No } & \multirow[t]{2}{*}{ Desa } & \multicolumn{2}{|c|}{ Jumlah penduduk } & \multirow{2}{*}{$\begin{array}{c}\text { Luas } \\
\text { Wilayah }\end{array}$} & \multirow{2}{*}{$\begin{array}{c}\text { Kepadatan } \\
/ \mathrm{Km}^{2}\end{array}$} & \multirow[b]{2}{*}{ Sex ratio } \\
\hline & & Laki-laki & Perempuan & & & \\
\hline 1 & Bentek & 4.140 & 4.386 & 34,27 & 249 & 94 \\
\hline 2 & Gondang & 4.328 & 4.586 & 29,20 & 305 & 94 \\
\hline 3 & Genggelang & 5.653 & 5.773 & 29,21 & 391 & 98 \\
\hline 4 & Rempek & 3.975 & 3.088 & 30,89 & 261 & 97 \\
\hline 5 & Sambik Bangkol & 2.833 & 3.037 & 30,78 & 191 & 93 \\
\hline & Jumlah & 20.929 & 21.870 & 157,35 & 272 & 96 \\
\hline
\end{tabular}

Sumber : Kecamatan Gangga dalam AngkaTahun 2018.

Berdasarkan hasil pendataan penduduk di Kecamatan Gangga jumlah penduduk sebanyak 42.799 jiwa, penduduk laki laki berjumlah 20.929 ( 48,90 persen ) dan perempuan berjumlah 21.870 ( 51,10 persen ), dengan sex ratio 0,96 artinya dari 100 orang perempuan terdapat 96 laki laki. Kepadatan penduduk sebanyak 272 jiwa per $\mathrm{km}^{2}$. Desa yang terpadat adalah Desa Genggelang dengan kepadatan 391 jiwa $/ \mathrm{Km}^{2}$, kemudian diikuti oleh Desa Gondang dengan kepadatan 305 jiwa / $\mathrm{Km}^{2}$. Sedangkan desa yang jarang kepadatannya adalah Desa Sambik Bangkol dengan kepadatan 191 jiwa / Km².

\section{Sosial dan Budaya Masyarakat}

Masyarakat yang mendiami wilayah Kecamatan Gangga merupakan penduduk asli (Suku Sasak) dan menggunakan bahasa Sasak sebagai bahasa pengantar seharihari. Ditinjau dari aspek sosial budaya atau adat istiadat masyarakat Kecamatan Gangga, masih erat atau kental dengan adat Sasak terlebih pada pesta perkawinan yang masih menggunakan aturan dan ketentuan adat Sasak walaupun sedikit 
banyaknya modernisasi telah mempengaruhi masyarakat yang dapat kita lihat dari cara berpakaian sehari-hari utamanya pada pemuda. Ini membuktikan bahwa masyarakat menerima atau terbuka terhadap hal-hal yang baru. Dalam menjalankan aktifitas sehari-hari, masyarakat setempat dikenal sebagai masyarakat pekerja keras serta semangat kegotong-royongan atau tingkat partisipasi masyarakat yang tinggi dan ramah.

\section{Jenis Penggunaan Lahan}

Penggunaan lahan yang ada di Kecamatan Gangga adalah bangunan, pertanian lahan kering campuran, savana, sawah, dan semak belukar.

Dari data dapat dilihat bahwa penggunaan lahan yang ada di Kecamatan Gangga lebih besar digunakan untuk kegiatan perekebunan dengan persentase sebesar 62,05 persen dari total luas Kecamatan Gangga. Ini sesuai dengan potensi Kecamatan Gangga sebagai kawasan perkebunan. Penggunaan yang sedikit untuk bangunan / pekarangan hanya sebesar 1,44 persen.

\section{Aspek Kunjungan Wisatawan}

Jumlah wisatawan yang berkunjung di lokasi kawasan wisata sangatlah penting dalam usaha pengembangan, diversifikasi obyek wisata dan daya dukung obyek. Oleh karena itu dibutuhkan data jumlah kunjungan wisatawan pada obyek wisata tersebut sehingga dapat diprediksikan kecenderungan (trend) yang muncul juga dampak negative yang akan ditimbulkan oleh wisatawan terhadap obyek dan daya dukungnya. Jumlah wisatawan yang melakukan kunjungan di lokasi kawasan tersebut dari tahun 2014 - 2017 mengalami peningkatan kunjungan jika dibandingkan pada tahun 2016. Hal itu terjadi karena seiring bertambahnya minat kunjungan masyarakat untuk mengunjungi kawasan wisata yang bersifat modern maupun wisata alam.

Tabel 2. Jumlah Kunjungan Wisatawan di Kecamatan Gangga Tahun 2014 -2018

\begin{tabular}{|c|c|c|c|}
\hline No & Tahun & Wisatawan (Jiwa) & Pertambahan/Penurunan (Jiwa) \\
\hline 1 & 2014 & 7.514 & 451 \\
2. & 2015 & 7.965 & 78 \\
3. & 2016 & 8.043 & 191 \\
4. & 2017 & 8.234 & -2.478 \\
5. & 2018 & 5.756 & 1.242 \\
\hline \multicolumn{2}{|c|}{ Jumlah } & 40.512 & \\
\hline
\end{tabular}

Sumber : Kecamatan Ganggar dalam Angka Tahun 2018 
Dari data di atas dapat disimpulkan jumlah wisatawan yang berkunjung ke lokasi wisata Kecamatan Gangga dari tahun 2014 - 2017 terus mengalami peningkatan. kemungkinan meningkatnya minat masyarakat untuk menikmati wisata alam, mencari udara segar sambil memetik buah ataupun sayur. Tapi pada Tahun 2018 terjadi penurunan secara drastis jumlah wisatawan, karena terjadinya bencana gempa yang menyebabkan wisatawan lokal dan Manca Negara tidak berkunjung ke Lombok, khususnya Lombok Utara, karena pusat gempa di Lombok Utara.

Partisipasi Masyarakat Lokal Dalam Pengembangan Agrowisata di Kecamatan Gangga,

Partisipasi masyarakat dalam pembangunan merupakan hal yang penting ketika diletakkan atas dasar keyakinan bahwa masyarakatlah yang paling tahu apa yang dibutuhkan. Partisipasi yang hakiki akan melibatkan masyarakat dalam keseluruhan tahapan pengembangan, mulai dari proses perencanaan, pengambilan keputusan, dan pengawasan program pengembangan Agrowisata. Keikutsertaan masyarakat ini sangat dipengaruhi oleh kemauan, kesempatan, dan kemampuan dari masyarakat tersebut Keikutsertaan masyarakat dalam perencanaan
Agrowisata dapat mendorong mereka berpartisipasi aktif dalam pelaksanaan dan pengawasan. Berdasarkan hal tersebut dapat dirumuskan model pengembangan pariwisata berbasis masyarakat. Berikut ini akan dijelaskan partisipasi masyarakat dalam keseluruhan tahap pengembangan sebagai berikut.

\section{Partisipasi Masyarakat dalam Tahap}

\section{Perencanaan}

Dalam menentukan derajat partisipasi masyarakat dalam tahap perencanaan Indikator yang dipakain adalah keterlibatan dalam identifikasi masalah, perumusan tujuan, dan pengambilan keputusan terkait pengembangan Agrowisata.

Dari hasil wawancara kami dengan masyarakat Gangga khususnya pelaku wisata, meskipun mereka diundang dalam beberapa rapat perencanaan, partisipasi yang dilakukan oleh masyarakat pada tahap ini tergolong semu. Benefit yang diperoleh dari bentuk partisipasi yang dilakukan tidak menunjukkan hasil yang signifikan, bahkan umpan balik yang disampaikan oleh masyarakat lokal atas keputusan yang diambil oleh penguasa sering diabaikan. Namun, selalu dihadang oleh keputusan penguasa yang bersifat topdown. Mekanisme seperti ini menjadikan masyarakat Gangga tidak 
terbiasa berpartisipasi. Kondisi ini berakibat pada kurangnya respons, antusiasme, dan keterlibatan masyarakat dalam pengelolaan dan pengembangan aset-aset di wilayah mereka.

Berdasarkan hal tersebut difahami bahwa kesempatan untuk berpartisipasi bagi masyarakat belum terbuka lebar. Masyarakat memiliki kemauan yang besar untuk turut berkontribusi dalam pembangunan wilayahnya, namun kesempatan untuk mengemukakan pendapat dan mengambil keputusan tidak tersedia. Hal ini disebabkan pemerintah telah memiliki rencana pembangunan yang telah dicanangkan sejak tahun-tahun sebelumnya, sehingga masyarakat hanya sebagai objek dari perubahan yang ada. Isu menarik lainnya adalah keterwakilan masyarakat Pendapat salah seorang responden, kami diundang pada saat ada rapat, tapi kebanyakan kami hanya datang dan mendengarkan sosialisasi mereka, tapi keputusan ada ditangan pemerintah

\section{Partisipasi Masyarakat Lokal dalam} Tahap Implementasi

Partisipasi masyarakat dalam tahap implementasi Parameternya adalah keterlibatan di dalam pengelolaan usahausaha pariwisata, misalnya, sebagai pengelola penginapan, pengelola rumah makan, pemandu wisata, karyawan hotel, dan pengelola atraksi wisata. Keterlibatan masyarakat lokal dalam tahap implementasi dalam arti pemanfaatan peluang terlihat mulai ada. Sekalipun wujud partisipasi itu ada, bentuknya lebih pada pengelolaan usaha berskala kecil.

Masyarakat Gangga dengan kompetensi bisnis yang rendah dan keterbatasan modal menyebabkan mereka tidak mampu bersaing dengan para pemilik modal besar yang umumnya berasal dari luar desa. Ironisnya, para pemilik modal besar tidak hanya menekuni usaha berskala besar, juga mengambil alih usaha berskala kecil yang pada mulanya dikelola masyarakat lokal. Akibatnya, sebagian besar hasil usaha tersebut tidak terdistribusi di tingkat lokal melainkan mengalir keluar desa.

Dari beberapa responden yang diwawancara ada diantara meraka yang memiliki penginapan berupa bungalow yang sering disewa oleh para turis asing. Turis asing menyukai suasana desa dan berbaur langsung dengan masyarakat setempat.

Masyarakat local sudah ada yang memulai usaha dibidang Agro dengan menanam Melon organik ( berkelopmpok), dengan harapan, wisatawan yang menikmati pemandangan alam / air terjun, diajak juga untuk menikmati buah melon dengan cara memetik dan menikmati langsung di 
tempat dengan cara /khas desa, Mereka ingin Kecamatan Gangga mempunyai brand khusus dalam agrowisata yakni menanam melon yang warnamya Orange. Alasannya, kalau Sembalun terkenal dengan Strobery, Lombok Tengah dengan Semangkanya maka kedepan Gangga terkenal dengan melonnya.

\section{Partisipasi Masyarakat Lokal dalam}

\section{Tahap Pengawasan}

Masyarakat lokal memiliki peran kontrol yang sangat substansial dalam pengembangan Agrowisata karena control terhadap proses pengambilan keputusan harus diberikan kepada mereka yang nantinya menanggung akibat pelaksanaan pengembangan termasuk kegagalan atau dampak negatip yang terjadi akibat pengembangan Agrowisata. Oleh karena itu, kewenangan pengambilan keputusan harus diberikan kepada masyarakat lokal. Indikator partisipasi masyarakat dalam pengawasan adalah keterlibatan dalam tim pengawasan berikut kewenangan yang dimiliki

Keterlibatan masyarakat lolal dalam melakukan pengawasan terhadap pengembangan Agrowisata terlihat minim. Alasannya, karena perencanaan pengembangan dilakukan oleh pemeritah tanpa melibatkan masyraakat, sehingga masyarakat tidak berkompetensi untuk melakukan pengawasan, dan merasat tidak perlu untuk melakukan pengawasan terhadap apa yang terjadi di sekitar mereka.

Pengawasan yang bersifat lebih kompleks seperti pelanggaran tata ruang, pelanggaran kawasan asri, sebagian besar warga bersikap tidak peduli, padahal secara substansi seharusnya masyarakat lokal ikut mengawasi. Selama ini pengawasan yang bersifat kompleks hanya dilakukan oleh segelintir masyarakat yang kritis termasuk elite masyarakat lokal.

Model Pengembangan Desa Wisata Berbasis Masyarakat

Partisipasi masyarakat dalam pengembangan desa wisata pada prinsipnya adalah partisipasi dalam mengelola sumber daya. Oleh karena itu, perlu dirumuskan model yang relevan dalam pelaksanaan program tersebut. Model dipandang sebagai acuan dalam merencanakan, mengimplementasi, dan mengevaluasi program. Sebagai sebuah pendekatan, model yang dirumuskan harus merepresentasikan partisipasi masyarakat dalam setiap aspeknya.

Untuk menjamin hal itu dirumuskan halhal sebagai berikut. (1) pengembangan Agrowisata harus berpedomanan pada kebudayaan local masyarakat; masyarakat lokal menjadi sentral dan 
menjadikan subjek dari semua proses pengembangan Agrowisata. Dengan menempatkan masyarakat sebagai sentral diharapkan partisipasi masyarakat sebagai pemilik sumber daya pariwisata akan terdorong dan mampu menyejahterakan masyarakat local; (3) pengembangan desa wisata membutuhkan adanya kemitraan yang solid antara tiga unsur utama, yaitu pemerintah, swasta, dan lembaga, yang masyarakat lokal menjadi pemangku kepentingan dari kerja sama tersebut; (4) ketiga pemangku kepentingan tersebut berada pada posisi yang sejajar dalam melakukan kerja sama serta saling menghormati; (5) fokus utama pengembangan Agrowisata adalah memperkuat kemampuan masyarakat lokal dalam mengarahkan dan mengatasi aset-aset yang ada pada masyarakat local untuk memenuhi kebutuhannya.

Pelaksanaan hubungan antar pemangku kepentingan tersebut terarah, peran dan tanggung jawab masing-masing harus jelas. Peran dan kewenangan masingmasing pemangku kepentingan sebagai berikut.

Peran dan Kewenangan Pemerintah, (1) melakukan penataan dan konservasi lingkungan fisik kawasan yang menjadi ciri khas Agrowisata; (2) melakukan perbaikan/pengadaan infrastruktur persampahan dan sanitasi; (3) melakukan gerakan masyarakat untuk mewujudkan sapta pesona; (4) melakukan pembuatan informasi dan fasilitas kepariwisataan; (5) melakukan perbaikan/peningkatan kualitas ruang publik, pedestrian dan landscape desa/lingkungan untuk mendukung sapta pesona; dan (6) dukungan pemberdayaan terhadap kelompok sadar wisata (Pokdarwis) dalam pelestarian lingkungan pariwisata (kawasan Hutan, dan sawah).

Peran dan Kewenangan Swasta (Investor, Perguruan Tinggi, LSM, pelaku pariwisata lainnya), yaitu (1) melakukan promosi terintegrasi antar pengelola objek wisata untuk menggerakkan kunjungan wisatawan antar objek wisata; (2) pembuatan dan pemasaran paket-paket wisata yang kompetitif yang terjangkau masyarakat; (3) pelatihan kewirausahaan, pelatihan keterampilan individual terkait usaha di bidang pariwisata (pelatihan bahasa Inggris, pelatihan hospitality, pelatihan mengenal budaya, dan karakteristik wisatawan dalam dan luar negeri); dan (4) pengembangan kelompok usaha bersama masyarakat;

Peran masyarakat Lokal, yaitu menyediakan sebagian besar atraksi sekaligus menentukan kualitas produk wisata. (2) pelaku budaya, misalnya, 
kesenian yang menjadi salah satu daya tarik wisata; dan (3) penyedia akomodasi dan jasa pemandu wisata, penyediaan tenaga kerja, produk makanan khas, kerajinan lokal, kesenian lokal, dan sebagainya.

Peran dan Kewenangan Badan Pengelola, yaitu (1) badan pengelola sebagai pengelola utama dan pengarah dalam perlindungan, perawatan, pelestarian guna mempertahankan fungsinya sebagai Agro wisata (cultural and natural heritage); (2) melakukan pengaturan yang diperlukan dalam rangka pengembangan Agrowisata Gangga; (3) menyediakan dan mengoperasikan segala fasilitas untuk menunjang kegiatan usaha; (4) memberikan dan mencabut izin penempatan, menetapkan persyaratanpersyaratan, dan menetapkan serta melakukan pungutan segala usaha komersial di Agrowisata Gangga; (5) menetapkan dan memungut biaya/retribusi dan pungutan lainnya atas pemanfaatan fasilitas yang tersedia dan hasil seluruhnya merupakan pendapatan badan pengelola; (6) melakukan perencanaan dalam bidang pengembangan atraksi/produk wisata, pengembangan fasilitas wisata dan (7) melakukan evaluasi dan pengawasan terhadap aktivitas kepariwisataan agar tercapainya tujuan pengembangan desa wisata yang berkelanjutan

\section{KESIMPULAN DAN SARAN}

\section{Kesimpulan}

Berdasarkan hasil perhitungan analisis yang telah dilakukan maka didapatkan kesimpulan dari penelitian ini, ialah:

1. Peran pemerintah dalam pengelolaan sumber daya pariwisata terlihat dominan.

2. Masyarakat belum menjadi subjek utama pembangunan, namun masih menjadi objek pembangunan. Hal ini disebabkan kesempatan untuk berpartisipasi masih terbatas.

3. Keran untuk berpartisipasi masih belum terbuka lebar. Masyarakat merasa tergusur oleh perubahan yang terjadi tanpa memiliki kemampuan untuk turut terlibat dalam pembangunan.

\section{Saran}

1. Masyarakat lokal khususnya masyarakat Kecamatan Gangga perlu diajak untuk mendesain sendiri model pariwisata yang akan dikembangkan

2. Pengembangan Agrowisata berjalan sesuai dengan kebutuhan masyarakat, harus ada jaminan masyarakat untuk terlibat di dalamnya, karena selama ini masyarakat terbiasa menjalankan apa 
yang diperintahkan oleh pemerintah dan tidak dibiasakan berpartisipasi. pemanfaatan tanah utk membuka usaha.

3. Perlu dibuatkan Awig Awig desa tentang menjaga ODTW ( Destinasi ) dan

\section{DAFTAR PUSTAKA}

Bappeda, 2018, Rencana Tata Ruang Wilayah Kabupaten Lombok Utara, Kantor Bappeda Kabupaten Lombok Utara Tahun 2017

Dinas Pariwisata Kabupaten Lombok Utara 2018, Rencana Induk Pengembangan Pariwisata Daerah (RIPPDA) Kabupaten Lombok Utara

Fandeli, C. 1995. Dasar-dasar Manajemen Kepariwisataan Alam, Liberti. Yogyakarta Jayadinata, T. J. 1986. Tata Guna Tanah dalam Perencanaan Pedesaan, Perkotaan, dan Wilayah, ITB. Bandung Kabupaten Lombok Utara dalam Angka Tahun 2017. Kantor Badan Pusat Statistik Provinsi Nusa Tenggara Barat, Mataram, 2018 , Kecamatan Gangga dalam Angka Tahun 2017. Kantor Badan Pusat Statistik Provinsi NTB, Mataram

Marpaung, H, 2000. Pengetahuan Kepariwisataan, Alphabeta, Bandung.

Muh. Amran Amir. Analisis SWOT. http://media-amran.blogspot.com/2010/08/analisisswot.html. (24 Oktober 2017)

Pendit, N. S. 1994. Ilmu Pariwisata Sebuah Pengantar Perdana. Pradnya Paramitha Jakarta. Pinata, I Gede dan I Ketut Surya Diarta. 2009. Pengantar IImu Pariwisata. Yogyakarta Suara Merdeka, 11 Januari 2015. Potensi Agrowisata dan Strategi Pengembangan Agrowisata Titi Yuniarti dkk, 2018: Strategi Pengembangan Potensi Kecamatan Gangga Sebagai Kawasan Agrowisata Di Kabupaten Lombok Utara. FEB Unram 2018

UU NO 102009 Tentang Kepariwisataan

Wahab, S, 1997. Manajemen kepariwisataan, PT. Pradnya Pariwisata, Jakarta.

Yoeti, A. O. 1982. Pengantar Kepariwisataan, Sebuah Pengantar Perdana, Pradya Paramitha, Bandung. 